Ranko Bugarski

Faculty of Philology

University of Belgrade
UDC 81'272

$323.15: 81 ' 272$

DOI https://doi.org/10.18485/fid.2017.7.ch2

\title{
THE EUROPEAN CHARTER FOR REGIONAL OR MINORITY LANGUAGES COMES OF AGE
}

У овом раду аутор, члан Међународног комитета стручњака за Повељу, истражује мотиве који се налазе иза овог значајног документа Савета Европе, јединог правно обавезујућег међународног споразума, чији је циљ да штити и промовише употребу традиционалних регионалних или мањинских језика, њену историју и структуру, процедуру и надгледање примене документа, проблеме у његовој примени, као и постигнућа након 18 година рада, укључујући изгледе за будућност. Посебан нагласак је на статусу мањинских језика у Србији и, у мањој мери, у другим државама наследницама бивше Југославије од којих су све осим једне приступиле Повељи у различито време. Такође су дате информације о земљама које су се придружиле Повељи и о језицима које она штити.

Кључне речи: Европска повеља, регионални језици, мањински језици.

\section{Introduction}

The protection of minority communities and their languages on European soil is an important concern of the Council of Europe, the oldest panEuropean institution which now has 47 members (all the states of Europe except Belarus, totalling some 800 million inhabitants). Since its inception the Council has concentrated on the advancement of human rights, parliamentary democracy, the rule of law and the promotion of common values. Its ultimate aim, shared with the European Union, has been the creation of a European identity, one superimposed on national specificities rather than obliterating them - a roof under which nations and citizens might enjoy a richer and more peaceful life than was possible when distinct and self-sufficient nation states, often mutually antagonistic, held full sway.

As part of the efforts to advance the mechanisms of defining and protecting human and especially minority rights, the Council's agenda included questions concerning language. Thus measures were taken in order 
to preserve several dozen minority languages, many of them threatened with extinction but as a rule neglected in the language policies of member states. An important and far-reaching long-term project aimed at safeguarding this endangered aspect of Europe's cultural heritage, traditionally an object of intolerance and discrimination, was launched in 1992, when the Council adopted the European Charter for Regional and Minority Languages. This extensive document substantially complemented and specified the language rights provisions contained in the Council's two related key instruments, the European Convention on Human Rights and the Framework Convention on the Protection of National Minorities.

The Charter was offered for signature and ratification to all member states, and it entered into force on 1 March 1998, after the first five states had ratified it. These were subsequently joined by others, the number reaching 25 out of the 47 at this writing (May 2015). The list follows, in alphabetical order: Armenia, Austria, Bosnia and Herzegovina, Croatia, Cyprus, Czech Republic, Denmark, Finland, Germany, Hungary, Liechtenstein, Luxembourg, Montenegro, Netherlands, Norway, Poland, Romania, Serbia, Slovak Republic, Slovenia, Spain, Sweden, Switzerland, Ukraine, United Kingdom. This shows that the Charter has so far been ratified by just over half the member states. Eight states signed but have not ratified to date: Azerbaijan, France, "FYR Macedonia", Iceland, Italy, Malta, Moldova and Russian Federation. And fourteen states never even signed: Albania, Andorra, Belgium, Bulgaria, Estonia, Georgia, Greece, Ireland, Latvia, Lithuania, Monaco, Portugal, San Marino and Turkey. Six of the non-ratifying states (Albania, Azerbaijan, Georgia, Moldova, Russian Federation and "FYR Macedonia") have so far abstained although this was a commitment undertaken when joining the Council of Europe, and are occasionally reminded of the fact, as in a declaration of the Council's Congress of Local and Regional Authorities of 10 February 2014. At any rate, the document remains open for accession.

The Charter's goal is to protect and promote regional or minority languages as an essential but endangered part of the history, tradition and identity of the states and regions where they are spoken, and thereby of the common cultural heritage of the continent. Its principal task is enabling the speakers of these languages to use them freely in private and public life. As 
stressed in its Preamble, the ultimate aim is contributing to the emergence of a Europe founded on principles of democracy and cultural diversity, while respecting the national sovereignty and territorial integrity of each member state. From this it follows that the primary objective of the Charter is of a cultural rather than political nature: conceived so as to protect endangered languages and not linguistic minorities themselves, it is dedicated to advancing the institutional mechanisms supporting the continued use of those languages as a cultural asset of Europe. Its focus, then, is on the possibilities of using languages, not on the language rights of their speakers. (With some natural overlap, the latter concern falls within the purview of the Framework Convention, which entered into force in the same year as the Charter).

\section{Structure}

In addition to the introductory and concluding chapters of a declarative and procedural nature respectively, the Charter contains two normative parts, II and III, which define the commitments of the acceding states. Part II outlines the general principles and goals, such as recognising regional and minority languages as a source of cultural riches of the community, preventing discrimination and intolerance towards them, facilitating their use, ensuring their teaching and study at all appropriate levels, etc. This Part holds for all states and all languages traditionally spoken in them, even if they are not individually listed in the ratification documents or reports of the acceding states: accepting commitments of this order is taken for granted always and everywhere. Part III, on the other hand, specifies these general principles through a set of practical measures, taking into account the particularities of each state and the different situations of its languages with respect to the main areas of their public use. These areas

are (1) education, (2) judicial authorities, (3) administrative authorities and public services, (4) media, (5) cultural activities and facilities, (6) economic and social life, and (7) transfrontier exchanges. This Part applies only to those languages which each state names individually in its instrument of ratification as belonging to the category of regional or minority languages in the sense of the Charter, undertaking to apply specific measures to them. (There is no predetermined list of such languages for any state or for Europe as a whole; each signatory is entitled to draw up a list for its own ter- 
ritory. As of 1 May 2015, the Charter covers a total of 79 languages used by 203 language groups in the 25 countries).

For the languages thus registered, variously "according to the situation of each language" or else uniformly for all of them, the state chooses at least 35 out of 68 precisely formulated measures from a common menu offered, which allows for different kinds and degrees of protection in each area of use, under the proviso that all the areas except the last must be represented in the selection made. (Thus, for example, one may opt for preschool, elementary, secondary or higher education; for only radio or also TV broadcasts; for daily or weekly newspapers; and so on). As a rule, "stronger" options should be chosen for languages with a larger number of speakers in a homogeneous community, the "weaker" ones for those in a less favourable situation. Hence a higher degree of protection may be guaranteed to the so-called "territorial" languages, while those "non-territorial" (like Romani or Yiddish) usually present special problems because their speakers are dispersed; for example, it is often difficult to gather in one place enough pupils for a class in such a language.

The Charter, as the only internationally binding document of its kind in existence, represents a systematized legal framework, a set of standards recommended to Council of Europe member states with the aim of protection and promotion of the regional or minority languages on their territories, including under this heading also the less widely used official languages. The collective formal definition of "regional or minority languages" will be cited below; at this point we may note the terminological difference between the two classes. In both instances we are dealing with languages used by a smaller part of a state's total population, but "minority" languages are those not spoken by a majority in any part of the state ("absolute" minority), whereas "regional" languages are spoken by a majority in some part of it ("relative" minority). The latter, usually strong numerically, may or may not be associated with an ethnically specific population group, or enjoy official status on their territories; examples are Catalan, Galician, Occitan, Low German. Importantly, however, special emphasis is placed on the principle that the application of the undertakings in no way relieves the speakers of such languages of the obligation to know and use the national or official language, or languages, of the state 
they live in. In this manner multilingualism and interculturalism, as crucial components of European integrations, are encouraged without compromising the identity and integrity of the individual states.

\section{Procedure}

As already implied, state signatories are free to decide on the number and selection of languages under Part III, as well as on the extent of guaranteed measures of protection. In addition, they may subsequently add further languages to their list, or new commitments to those previously undertaken. It is also possible to withdraw a ratification (which has only happened once, and temporarily, in the case of Ukraine). Yet all this does not mean that the signatories' discretion knows no bounds; on the contrary, all their choices and decisions must be fully in line with the principles and objectives laid down in the Charter, and accepting the commitments should be taken seriously, since it implies some clearly defined responsibilities.

As regards the number and selection of languages, member states have made choices reflecting their own circumstances and objectives; for illustration we shall supply some data only for the former Yugoslav republics. Croatia was the first to join, in 1997, ratifying in Part III for seven territorial languages (Czech, Hungarian, Italian, Serbian, Slovak, Rusyn and Ukrainian). Slovenia came next, in 2000, with only Hungarian and Italian as autochthonous minority languages, and some special protection for Romani. The short-lived "State Union" of Serbia and Montenegro signed in March and ratified in December 2005; since the Montenegrin declaration of independence, the official reckoning is that the Charter came into force separately in Serbia and Montenegro in June 2006. The Serbian ratification covers ten Part III languages, all with identical undertakings (Albanian, Bosnian, Bulgarian, Croatian, Hungarian, Romanian, Romani, Rusyn, Slovak and Ukrainian). Montenegro singled out Albanian and Romani. Bosnia and Herzegovina signed in 2005 but ratified only in 2010 as the last to date, for as many as 17 Part III languages (Albanian, Czech, German, Hungarian, Italian, Jewish /i.e. Yiddish and Ladino/, Macedonian, Montenegrin, Polish, Romanian, Romani, Rusyn, Slovak, Slovenian, Turkish and Ukrainian). Macedonia, having signed as early as 1996, has still not 
ratified. In most of these states there are additional languages to which only the general Part II measures apply; in Serbia, for instance, Bunjevac, Czech, German, Macedonian and Vlach fall into this category.

The implementation of the undertakings is subject to systematic monitoring by a special Committee of Experts on the Charter, composed of one member from each state signatory. These are elected by the Committee of Ministers of the Council of Europe, from among three candidates nominated by the state upon ratification, with a six-year renewable mandate.The experts act independently and not according to instructions from their countries' governments.

The Committee examines the reports submitted by member states periodically (the first a year after joining the Charter and thereafter every three years), sends out working groups for talks with representatives of the state's institutions, of the minorities and of civil society, and on the basis of all the information gathered produces its own evaluation report. This document, containing judgements on the implementation of the commitments undertaken and recommendations for improvements, is after adoption by the Committee of Ministers sent to the authorities of the state in question. Although there are no formal sanctions for possible evasion of responsibilities, the states generally comply with the suggestions made as circumstances permit. The Council's Secretary General submits his own report on the implementation of the Charter to the Parliamentary Assembly every two years. All these reports are made public on completion of the respective cycles.

Applying the Charter thus involves three principal partners: the Council of Europe, relevant institutions of state signatories, and civil society (NGOs or other representatives of speakers of minority languages). This last because it is held that adequate and successful measures can only be taken in the constructive cooperation of the state and the speakers, which also facilitates continuing contact between the different language groups within the country as well as across borders.

\section{Problems}

Over the years a variety of problems have come up in the process

of applying the Charter. Some of them arise from the sociolinguistic situ- 
ations of the countries concerned, vastly different even in number of their languages (which at present varies between 1 for Denmark and 20 for Romania). Typologically, some of these are majority and official languages in one country but minority languages in other, usually neighbouring ones (e.g. German, Ukrainian, Serbian, Hungarian). Others always have minority status, be it in several states (e.g. Romani, Yiddish) or in just one (e.g. Welsh and Scottish Gaelic in the UK, Upper and Lower Sorbian in Germany). Furthermore, regional and minority languages in the same state very often differ drastically in size; we thus find a range from some six million speakers of Catalan to 5,000 for Aranese in Spain; from 500,000 for Hungarian to 2,500 for Polish in Slovakia; or from 300,000 for Swedish to a mere 250 for Inari Sami in Finland.

Another set of problems derives from certain shortcomings or ambiguities in the text of the Charter, starting with the very definition of basic concepts.Article 1 states that for the purposes of the Charter

"regional or minority languages" means languages that are i. traditionally used within a given territory of a State by nationals of that State who form a group numerically smaller than the rest of the State's population; and ii. different from the official language(s) of that State; it does not include either dialects of the official language(s) of the State or the languages of migrants.

The problem here is the nonexistence of firm and generally valid criteria for differentiating languages from dialects; as a rule this is a sociological and political question rather than a strictly linguistic one, and is as such subject to variable interpretations in different national or social contexts. For example, Scandinavian countries are home to nine Sami dialects, some of them mutually incomprehensible, which are for administrative or political reasons sometimes treated by the states as a single "Sami language" - which in Norway enjoys official status along with Norwegian, so that it seems paradoxical to secure minority protection for a country's official language. Another special problem is "the Romani language", in reality a conglomeration of different dialects under various local names.

The weaknesses of the states' freedom in deciding on which languages will be protected and with what measures have also come to the 
fore. Many of them have opted for a minimalist solution, i.e. for easier undertakings which would mainly reflect the already existing state of affairs, or even go below that. Conversely, some other states have taken a maximalist course, guaranteeing unattainable levels of protection to an unrealistically high number of languages. A striking example is Bosnia and Herzegovina, whose extraordinary plethora of registered languages mainly consists of idioms with few speakers - or practically none, in the case of Ladino and Yiddish. In the latter instance one might say that the state authorities have proceeded in a politically opportune but careless fashion, without fully realizing what they are committing themselves to with such generous ratifications.

Another source of difficulties is the fact that minorities often speak archaic dialects, very different from corresponding standard languages in the parent countries, as in the case of German in Switzerland and in central Europe. True, the precondition for Charter protection is traditional presence and a sufficient number of speakers in a given territory, regardless of possible standardization or official use - at least in principle. But even this can be questionable, for several reasons. First, it is impossible to determine the number of speakers deemed sufficient, so one must live with rough approximations - and besides, many Western countries, such as Sweden, Denmark or Germany, do not collect statistical data on the ethnic or linguistic affiliation of their citizens, which makes it hard to estimate the actual size of population groups. (The situation is better in the former socialist countries of Eastern Europe, where the ideology of "national equality" dictated gathering detailed information concerning minorities and their languages).

Second, certain measures, for example in education, do imply a standardized language variety. Further on, members of most minorities are normally bilingual, thus featuring dual affiliation, and sometimes even practically monolingual in the majority language, which may question the purpose of maintaining by artificial means a language which has all but lost its spoken base. And lastly, doubts have been raised concerning the territoriality principle, as increased mobility of populations can significantly change the demographic picture of a space.

This last remark reveals what is probably the Charter's major structural deficiency: the explicit exclusion of immigrant languages. In many 
host countries these idioms have far more speakers than the officially recognized languages of autochthonous minorities, and thus represent precisely the richest single source of linguistic diversity in present-day Europe. We may mention only the Turks in Germany and the Arabs in France, or the multilingual reality of the great urban agglomerations across the continent, but also the example of Slovenia, which initially recognized only Italian and Hungarian although it has several times more speakers of the former Serbo-Croatian varieties. The rejection of immigrant languages is mainly dictated by pragmatic reasons, as their inclusion would often make an already complex situation even more difficult to regulate in a rational and consistent way. However, it may have to be reconsidered in the future, the more so as such languages may in time be consolidated to the extent of becoming fully fledged candidates for Charter protection.

And having mentioned reconsideration, we may add that the Charter, conceived some twenty-five years ago, has by now become rather outdated in other respects too. This especially applies to the internet revolution that has taken place in the interim, which renders rather obsolete insisting on a state's obligation to secure, say, regular newspaper columns or radio and TV broadcasts in all its minority languages, when much of importance for their survival is more easily conveyed through the new, especially privateowned, media. This change is underscored by the fact that even the big national newspapers are now increasingly going online, as well as by the already widespread practice among the younger generations, who should be the chief safekeepers of endangered languages, of communicating exclusively through social networks in almost total disregard of print media, radio and television. Furthermore, experience has shown that improvements are needed in the process of the Charter's application, including the length of the reporting cycles (states have frequently disturbed the entire mechanism by late submissions). Yet no revisions are foreseen at present, for fear that any changes in the Charter's text might incite further demands and cause complications ultimately threatening the whole project.

Among the general problems are some of a psychological nature. Speakers of minority languages are often reluctant to use them in communication with the state, especially if they do not know them well, being fully conscious of the widespread stereotypes about them as somehow 
second-rate, even nationally suspect citizens. States are therefore strongly advised to make provisions for the actual use of these languages, and to inform the public at large about the presence and significance of minorities and their languages as an integral part of national identity and cultural heritage. But all this is of no avail if a minority simply does not wish to have its language protected, as in the extreme case of some Roma groups (like the Sinti in Germany) who cherish their idiom as an intimate possession which must not be revealed to outsiders.

Last but by no means least, there are often considerable practical difficulties in securing adequate personnel and materials for teaching, court proceedings, media and so on in the various minority languages, and above all the funds necessary for all that; lack of these sometimes serves as an excuse for failure to implement certain undertakings.

Other problems are specific to individual member states. In Serbia and Croatia, for instance, full implementation of the Charter is in some segments made difficult by national legislation, which imposes thresholds (say, $15 \%$ or $25 \%$ ) in the participation of a minority in a given population as a requirement for guaranteeing certain language rights. This, however, runs counter to the very spirit of the Charter, which is not concerned with percentages of speakers but with protection and promotion of languages wherever possible. Also, Serbia's choice of the same commitments for all its languages, motivated by reasons both ideological (equal treatment for all) and practical (relieving the state of the additional burden of nuancing the protective measures for so many languages), has had some notable negative consequences. Namely, in order to give something to languages low in numerical strength or current status (e.g. Bulgarian, Ukrainian, Romani), this egalitarian arrangement inevitably shortchanged the higher-ranking ones (e.g. Hungarian, Slovak, Romanian), which had already achieved a higher level of protection than that guaranteed by such a ratification. And this kind of situation, besides causing dissatisfaction among speakers of the latter languages, is explicitly ruled out by the Charter, whose application must never go below the previously achieved standards.

Even greater complications have arisen in France, where the Charter's fundamental principles directly collided with some centralist legal provisions - at least according to a controversial decree by its Constitu- 
tional Court, which proclaimed joining the Charter unconstitutional in view of an article, subsequently entered into the Constitution in 1992 (the very year when the Charter was adopted!), laconically declaring that the language of the Republic is French - and thus allegedly excluding the official use of any other language in certain domains stipulated by the Charter. Whatever the motive for this addition, it opened the authorities to constant criticism for evading ratification of a document signed already in 1999, and hence effectively suppressing the numerous regional and minority languages of France, the loudest promoter of the rhetoric of Europe's linguistic and cultural diversity in international forums. Finally, on 28 January 2014 the French National Assembly voted in favour of a constitutional amendment permitting ratification, whereby this dilemma might perhaps be resolved. Another case in point is Belgium, whose complex federative structure, along with the historically variable majority-minority relations of French and Flemish and the different legal treatment of minority languages, would call for separate ratifications by the two regions, which is impossible because acceptable parties to the Charter are only states, not their constituent parts.

Special problems can be caused by major changes in the administrative or even physical structure of states. Thus Ukraine signed in 1996 and ratified in 1999, cancelled this ratification a year later and ratified anew in 2003, with this second ratification coming into force only in 2006 . The main issue here centered on the Ukrainian language, after independence declared to be the national and official language of Ukraine, but in reality a predominantly rural and mostly less prestigious language than Russian, which maintained much of its high status from the Soviet era despite the recent official efforts at "derussification" and "ukrainization" of the country. In this situation, the policy of strengthening the position of Ukrainian in education, media and so on clearly contradicts the obligation to protect all its 13 minority languages - including Russian, whose promotion is neither needed nor desirable from the viewpoint of the state's policies. Further complications have set in with the recent loss of jurisdiction over Crimea, with its six minority languages (Bulgarian, Crimean Tatar, German, Greek, Karaim and Krimchak) for which Ukraine had guaranteed protection. The Committee of Experts on the Charter expressed its concern about this situation in a statement unanimously adopted at ts meeting on 
13-16 May 2014. Another example is Cyprus, which likewise ratified the Charter, but the division of the island caused a clash between the inherited constitutional provision about Greek and Turkish as official languages of the whole country and the present situation, where Turkish on the government-controlled territory still enjoys official status legally and therefore does not come under the Charter, whereas in reality it is an endangered language of a small minority, undoubtedly in need of such protection.

A peculiar development occurred in Montenegro with the postratification declaration of Montenegrin as its national official language, whereby Serbian, which had previously enjoyed that status, was downgraded to a minority language in official use, which would thus, despite being the strongest numerically, in principle fall under Charter protection. In other words, practically the same language - only under different names - simultaneously functions as the official language of the state and as the language of one of its minorities. The controversies surrounding the status of Serbian were temporarily overcome by Montenegro's declaration that according to its Constitution it is not a minority language in the sense of the Charter, a solution made easier by the fact that representatives of the Serbs, who do not see themselves as a minority, did not ask for such protection (as distinct from speakers of Croatian and Bosnian, to whom it was subsequently granted under Part II). A somewhat related situation, where the same language bears different official names in different parts of a single state, involves the language called Catalan in Catalonia itself and in some other parts of Spain but not in Valencia, whose authorities insist that a distinct language, Valencian, is spoken there.

A number of states of considerable interest in terms of minority languages have avoided joining the Charter altogether, for a variety of reasons. Estonia, Lithuania and Latvia, each with about ten minority languages of which Russian is by far the strongest, had struggled hard, and not without reverting to drastic undemocratic measures, to free themselves from the domination of Russian, and by acceding they would actually commit themselves to protecting it. Macedonia would have to promote Albanian, the language of its largest national minority, with which it entered into armed conflict in 2001, whereafter it had to recognize Albanian as its second official language. Ireland recognizes Irish as its national and first official language and English only as the second official language, even 
though Irish is spoken by a negligible percentage of the population and would as such come under the Charter's minority protection: a paradoxical position for the principal symbol of Irish identity. In Italy, given its great dialectal diversity and the ambiguities surrounding the very notion of the Italian language, it would often be hard to decide what should count as a language and what as a dialect in terms of the Charter; however, there have been signs of late that Italy may be moving towards accession. Albania, Greece, Bulgaria and Turkey do not grant official recognition to minorities or their languages in the relevant sense and therefore hardly fit into the Charter's framework, to say nothing of the political problems that would be entailed. In contrast, Iceland (and, erroneously, Portugal) are often cited as rare instances of a monolingual state, but their status should perhaps be reconsidered in the present context. At any rate, a positive example was offered quite early by Luxembourg and Liechtenstein, which lack minority languages in the sense of the Charter but joined it as an expression of solidarity with its goals.

The application of the Charter is often additionally complicated by the actual language situation in states (such as Ukraine or Spain) with numerous languages vastly different in size and social status, and with a complex administrative structure. The latter parameter is especially evident in Germany, where language policy is the responsibility of the many individual Länder and not of the federal state at all. So it is easy to understand the reluctance of the Russian Federation, with its possibly 130-160 candidates for protection, to ratify the Charter after signing it in 2001; however, this possibility has been explored by a special body in the Council of Europe.

Finally, there have on occasion been difficulties in the relations between the Council and the various state authorities, as well as in the work of the Committee of Experts and of the Charter Secretariat, an agile and efficient body which unfortunately suffers from chronic shortage of personnel and inadequate financial support.

\section{Achievements}

Despite the problems and limitations mentioned, because of which the Charter has not entirely justified the high initial expectations, its performance to date undoubtedly merits a positive overall mark. Above all, in 
challenging the traditional ideology of the monolingual nation state it has notably contributed to raising the general public's awareness of the importance of preserving the rich linguistic heritage of Europe. In other words, its application has increased the visibility of previously neglected minority languages everywhere, frequently providing recovery strategies for those most endangered. In this way it has highlighted the generally ignored fact that in nearly every European state there are minority languages deserving support.

In so doing, the Charter has advanced the status of numerous languages, including some which had already enjoyed official standing, in many ratifying countries, if necessary by initiating improvements in state legislation; some examples follow. The public perception of Romani dialects and in part of Yiddish has visibly improved in some states. In the United Kingdom, Scots was restored to its long-lost dignity, and revitalising measures have been applied to Cornish and Manx, Celtic idioms on the verge of extinction. In Sweden and Norway respectively, Meänkieli and Kven, formerly regarded as local dialects of Finnish, were granted independent language status. In Germany, the widespread Low German finally received recognition as a regional language in its own right, rather than an unwelcome country cousin of High German. Advancements were likewise made by Limburgish and Lower Saxon in the Netherlands, Kashubian in Poland, and Basque in Spain.

More recently, Serbia explicitly undertook to apply Part II protection to Bunjevac and Vlach, idioms in the initial stages of standardization and hence not listed in the ratification document, which represents a kind of formal recognition welcomed by the speakers. This is especially noteworthy since both languages have been hotly disputed - Bunjevac by the Croat minority in northern Vojvodina, encouraged by state authorities in Croatia, who claim that it is a mere dialect of Croatian, and Vlach by a minority of its speakers in eastern Serbia, strongly supported by Romania in claiming it for Romanian. As a result of these politically motivated disputes the Committee of Experts' second evaluation report on Serbia, which presented the situation objectively, was blocked in the Committee of Ministers for two full years, but was finally adopted without any changes in June 2013. Serbia also made a symbolically important gesture by entering Romani under Part III, thus contradicting its declared decision to grant 
such a status only to languages in official use in some part of her territory, a condition not fulfilled by Romani. This special treatment has in some measure contributed to improving the public image of this language and has initiated or supported various current projects aimed at its protection and promotion. In Montenegro, Croatian and Bosnian subsequently made it to the agenda, as noted, while German, Slovenian and Romani eventually did so in Croatia, and German, Croatian and Serbian in Slovenia.

And quite generally, the Charter has stimulated minority communities to actively participate in matters of common concern. This has led to an increased awareness of their rights among minority members and to a more positive attitude towards their languages, while on the other hand encouraging state authorities to address their responsibilities in this area more systematically - inter alia, by establishing a variety of cultural and pedagogical institutions, commissions and programmes for minority languages.

In conclusion, the achievements of the Charter after eighteen years of operation can be considered satisfactory, as it has successfully triggered a long-term, in fact unbounded process of creative social intervention in a previously rather neglected area. It remains a living testimony to the mutually enriching efforts of European states at advancing the quality of life on the continent and affirming some of the principal cultural values of our era, while at the same time offering a possible answer to the challenges of cultural and linguistic globalization which Europe is increasingly facing.

\section{Outlook}

Without in any way wishing to diminish the undoubtedly positive results achieved by the Charter, it must be admitted that predictions about its future development are less optimistic. For several years now there have been no new ratifications, and major absentees like Russia, France and Italy, having initially shown some willingness to join in, have proceeded in a halting manner, to say the least. This situation raises concern, particularly at a time when intolerance, nationalism and even racism among majority populations are on the rise across Europe. It is worth noting that, according to informed estimates of some high-ranking Council of Europe officials, both the Charter and the Framework Convention were luckily ad- 
opted while the overwhelming atmosphere was still favourable for drafting documents like these, whereas their chances of ever coming to life would in all likelihood be negligible under the conditions prevailing today. But be that as it may, the Charter's rich legacy deserves to be preserved and enriched as far as circumstances permit, both at present and in the future.

\title{
References:
}

The text of the Charter and related documents are accessible on Council of Europe websites, in English and French. - For the original published version in English, see European Charter for Regional or Minority Languages and Explanatory Report, 1993; with detailed comments also J.-M.Woehrling, The European Charter for Regional or Minority Languages: A Critical Commentary, 2005; and with accompanying documents, including statistical and other data, in European Charter for Regional or Minority Languages: Collected Texts, 2010 (all published by Council of Europe Publishing, Strasbourg). Discussion of the Charter's impact at its tenth anniversary may be found in Minority Language Protection in Europe: Into a New Decade, 2010, with the same publisher (who has also printed separate collections on the individual areas covered by the Charter, a detailed analysis of the work of the Committee of Experts, etc.). An up-to-date review of the Charter's application in all states ratifying for Romani, as a ubiquitous and particularly endangered language, is available in D.W.Halwachs, S.Klinge and B.Schrammel-Leber, Romani. Education, Segregation and the European Charter for Regional or Minority Languages, Graz: Grazer Romani Publikationen, 2013.

\begin{abstract}
In this paper the author, a member of the international Committee of Experts on the Charter, briefly surveys the motives behind this major Council of Europe document, the only legally binding international treaty aiming to protect and promote the use of traditional regional or minority languages, its history and structure, the procedure and monitoring of its application, problems in its implementation, and its achievements after
\end{abstract}


18 years of operation, including the outlook for the future. Information on the countries that have joined the Charter and on the languages protected by it is also provided. A special focus is on the status of minority languages in Serbia and, to a lesser extent, also in the other successor states of the former Yugoslavia, all but one of which have at different times acceded to the Charter.

Keywords: European Charter, regional languages, minority languages.

\section{Bibliographical statement}

RANKO BUGARSKI, PhD, was until his retirement Professor of English and General Linguistics, University of Belgrade. - He was also a Fulbright Lecturer in Linguistics, University of Chicago, and Visiting Professor of Linguistics, Northeastern Illinois University, and has given guest lectures at numerous universities in Europe, USA and Australia. His teaching, research and writing have been in the fields of English and general linguistics, applied linguistics, sociolinguistics, history of linguistics, etc. He is the author of over 20 books, as well as dozens of articles in international publications, and editor (with Celia Hawkesworth) of Language Planning in Yugoslavia (1992) and Language in the Former Yugoslav Lands (2004). His recent books include Jezik i identitet (Language and identity, 2010) and Portret jednog jezika (The portrait of a language, 2012). - He is the recipient of three Festschrifts. - Some of his previous or current positions: President (now Lifelong Honorary Member), Societas Linguistica Europaea; Vice President, Association Internationale de Linguistique Appliquée; member, Academia Scientiarum et Artium Europaea, Salzburg; corresponding member, Research Centre on Multilingualism, Brussels; Council of Europe expert on regional or minority languages, Strasbourg.

E-mail: rbugarski@fil.bg.ac.rs 